\title{
THE ROLE OF IT SYSTEMS IN SUPPORTING LOGISTICS SYSTEMS IN AGRIBUSINESS ENTERPRISES
}

\author{
Ludwik Wicki, Warsaw University of Life Sciences - SGGW, ludwik_wicki@sggw.pl \\ Justyna Franc-Dąbrowska, Warsaw University of Life Sciences - SGGW, justyna_franc_dabrowska@sggw.pl
}

\begin{abstract}
The aim of the research was to attempt to assess the role of IT systems in supporting logistics processes in agribusiness enterprises. The following research hypothesis was formulated: IT systems support logistics processes in agribusiness enterprises. Analysis shows that there is significant internal variation within the scope of the food production sector with reference to the scope of IT system use in logistics management. These results stem from the various features of the materials, level of concentration in the branch and the character of recipients. In the service of wholesalers or retail chains the implementation of IT systems is required at least within the scope of the management of orders.
\end{abstract}

Keywords: Information Technology (IT), logistic SME and agricultural enterprises

\section{INTRODUCTION}

The problematic aspects of supporting logistics systems in the economy using IT solutions (in its broad sense) have been the subject of vast analysis in recent years. On one hand an efficient flow of information and a systemic approach to the process is a fundamental condition, on the other the way of organization, implementation and functioning of logistics systems is important. This matter is an especially significant area of interest in agribusiness due to the fact that agribusiness enterprises are dependent on natural (biological) possibilities of the development and growth of plants and animals, while their logistics systems must particularly consider the needs associated with transport, storage and other activities concerning live organisms and food products. The change in EU food law in 2005 (such as the change of product identification from bar code to radio frequency identification - compare Grębowiec [14] is an additional factor worth emphasizing. Here the definition of logistics systems given by Abt, is worth noting. He believes that logistics systems constitute a purposefully organized and integrated flow of materials and products, in connection with information which is appropriate to them, which allows optimization in the management of the supply chain [1]. It is commonly used definition.

In agribusiness, as in the whole economy, there are strong tendencies towards increasing the role of logistics in creating positive value, decreasing costs and ensuring high quality food products to final recipients. At the same time the number of regulations concerning the food market is on the increase, including those associated with the necessity to ensure the identification of the origin of ingredients and semi-products in foods supplied to the market. The activities of enterprises have been observed over a larger geographical area. In polish conditions, this is a result of tightening integration between the markets of Poland and other EU Countries. Another reason is the increasing scale of production in food processing enterprises. The specification of perishable products (such as best before date and origin) is also strongly emphasized. In the conditions of an increasing number of trade contacts, efficient IT systems are required to support the management of provision, production and the supply chain.

\section{LITERATURE REVIEW}

Information is playing an increasing role in today's economy. It is treated as a more valuable resource than traditional material goods [20]. The management of the flow of goods and services and their accompanying information is the subject of logistics. Current logistics systems in various sectors of the economy, especially that of production, are supported by dedicated integrated IT systems. Computer Aided Logistic computer systems usually offer five basic functions: planning, coordination of the activities of particular areas of the firm, control, information / communication and analysis [20]. Three basic system categories can be distinguished: assisting basic activity (production), integrated assistance of provision and production and complex systems for the management of the entire logistics chain, integrating all participants of the supply chain. The term given to this integrated system is SCM (Supply Chain Management).

The main purpose of using IT technology in enterprises as well as applying uniform standards of data exchange and identification is maximizing the efficiency of the supply chain achieved thanks to ensuring 
automatic identification of logistics units and goods and ensuring automatic creation and exchange of documents.

An important problem of the role of IT systems in the improvement of the effectiveness of enterprises was raised by Kaleta i Toczyłowski [22]. They claimed that each participant of the IT system may increase its effectiveness by way of using tools provided by IT. However, individual improvement of effectiveness may not necessarily give a positive effect to the whole system. Therefore, the role of using IT systems in increasing enterprise effectiveness should be considered in a holistic perspective (compare the perception of IT project success through management described by Basten, Joosten and Mellis [5], or considering behavioral factors in the research of Fadel [10].

The basic technology used in the supply chain for the automation of reading and processing data is RFID and bar-code technology. Global standards are created by GS1. There are three basic identifiers which are commonly used: Global Trade Item Number (GTIN), Serial Shipping Container Code (SSCC), the Global Localization Number (GLN) and standard logistics labels. The effective use of these technologies is enabled solely by using EDI [20].

Borowiec [6] observes that the Internet is an important tool which enables the automation of the work of teams, also the Intranet or electronic mails as examples (e.g. Palonka [29] presents an interesting use of the Internet in logistics using e-logistics). Chwesiuk [7] emphasizes the value of possessing and the possibilities of using appropriate IT systems which assist in the decision making processes of enterprises. He draws attention to the fact that such systems may give the enterprise a competitive advantage. Lech [26], Hołubowicz and Samp [17] present similar views. Compare the opinions of Avila, Goepp and Kiefer [4], similarly - in the context of building an effective business organization - Wyrębek [38]). The implementation of such systems is one of the most difficult management tasks the enterprise faces. At the same time it is the biggest and most important IT objective of the enterprise. Similar observations can be found in the work of Grabowska [19] who defines the logistics information system as a system of assumptions, notions and modules and the dependencies amongst them which enable the description (modeling) of logistics processes taking place in the distribution channels. Grabowska pays attention to the important aspect associated with the role of information for it may reduce uncertainty, enable the assessment of risk, opportunities and threats connected with taking action. Grębowiec [14] makes a similar statement. Moreover, Hołubowicz and Samp emphasize that IT is necessary for the functioning of logistics enterprises. These authors point to the development of storage and logistics application as one of the fastest developing fields of the IT branch and though part of these logistic IT solutions is typical in all branches, some of them are exclusively dedicated to particular branches of industry, for example for food processing industry [17].

As Smal states in [33], the development of IT systems for logistics should enable the remote control of storage processes with the use of internet search engines. The primary factor for development however, is the adjustment of technologies to the needs of smaller firms and the flexibility of the system to enable its adjustment to the needs of the specific enterprise. Regular updates of programs and access to professional technical assistance is also important. As Klonowski [24] notices, for the informatization of management to be successful, an appropriate definition of the aims, strategy and implementation of informatization is necessary. Moreover, the selection of a suitable package of programs and implementation process is not without significance.

It is also important to highlight the importance of systems integration in SCM information flows which was discussed among others by Rai, Patnaiyakuni, and Seth in MIS Quarterly [30]. Based on the research performed they confirmed that integration between firms and its supply chain partners results in significant and sustained performance gains, especially in operational excellence and revenue growth.

\section{AREAS OF APPLICATION}

SAP, Oracle, JDA Software, RedPraire and i2 Technologies are amongst the most important global suppliers of SCM (supply chain management) software. Most of them offer complex solutions which belong to the class of SCP, WMS, TMS and MES (Manufacturing Execution System) [37]. Due to the high purchase and system implementation costs, most of the companies offer simplified systems with certain limited sets of standard functions. Cooperation in trans-regional markets with other firms with regard to the supply of semi-products and outsourcing part of the production within the scope of the supply chain [15] cause this to be a more frequently developed module of ERP systems similarly as in TMS [37]. However, research concludes that the main activity of firms from the F\&B sector concerns regional markets and less that of national ones [18]. 
The studies conducted by Kanicki conclude that the role of information systems in logistics is on the increase. This concerns the ERP class (ensuring automation of the exchange of information in the enterprise) as well as systems enabling the electronic exchange of information amongst the participants of the supply chain, particularly in contacts with suppliers. The ERP system is supported by the CSM and WMS systems and between the years 2009-2010 the popularity of ERP and SCM systems increased in all of the enterprises investigated by Kanicki, regardless of their size [23]. Moreover, Lech claims that ERP is a factor which enables the introduction of organizational changes [26]. One can therefore assume that the IT systems in logistics, especially the logistics of the food sector may enable organizational changes which may give a long-term competitive advantage and contribute to the improved financial situation of these enterprises.

In the production of food and beverages several key areas of importance with regard to the application of information exchange standards and other IT solutions are observed. The first refers to the planning and management of supply and production using ERP class systems. They should however be adjusted to the unique requirements of food processors and enable the use of many recipes as well as define the number of co-products. An important feature of such systems dedicated to the food processing branch should be orientation in the processes of production management [9]. Predefined standards for this branch must also be included such as the content of fat, protein, moisture of ingredient, $\mathrm{pH}$. These product characteristics are key in the management of supplies, production, quality and determine the production costs. The management of the supply chain must also be possible due to the necessity of meeting the legal requirements and ensuring the safety of food and guaranteeing the origin of its ingredients (for example no GMO s) [12, 13, 34, 36]. Competition between firms is currently changing into competition between supply chains. The approach in ERP processes and traceability are guaranteed by meeting quality system requirements (ISO, HACCP, GMP, EUREPGAP).

Next area of IT solution use is the prediction of demand for various seasons and time frames - weeks, months, quarters [15], making orders and payment on-line. Such a scope of using IT mainly concerns the B2B sector [18].

It is also important to have the possibility of quickly assessing the profitability of products, recipients, market segments, sales regions and distribution centres [9, 10] and transmission of Electronic Data Interchange (EDI), particularly for using Internet applications (for example in the software cloud) [10, 12]. Precise ordering and delivery of supplies, significant reduction of workload during the reception of products and its completion [2], management and control of supplies [9, 39] are further significant factors favouring the introduction of IT systems. IT systems enabling cooperation in the supply chain are often introduced because they are required by recipients such as retail and wholesale networks [18].

One of the most important functions concerns the possibility of tracing the origin of production parts. In the production of food this is necessary due to the various origin of materials used in production which are susceptible to rotting and the presence of bio-active materials [35]. Many authors claim that in the food supply chain, fresh food in particular requires IT system traceability support due to its complex structure [8]. Only thanks to IT systems is it possible to trace the country of origin of a given material and the products which are made from it [9].

\section{APPLIED SOLUTIONS}

The RFID system is an important solution associated with IT systems of (F\&B) enterprises. Tracing with the use of this technology has not only been observed in logistics firms but also in various branches of industry including food processing and agricultural supply [3, 11, 39]. GPS and WLAN technology is also used in some applications [39]. Some authors state that traceability takes place without IT technology and even bar codes and the cost of tracing small parts without the implementation of IT systems is very high [8]. The biggest problem is the distribution of information concerning the features of unprocessed materials and ready products [16].

One of the most important advantages of implementing IT systems concerns the significant reduction of data transmission costs. They are estimated at $10 \%$ of the cost of transactions using paper documents [2]. The use of RFID in the supply chain in agribusiness is beneficial as long as there are many product parts. Moreover, it is easy to identify the unit in the whole supply chain [32].

\section{SMALL AND MEDIUM SIZED ENTERPRISES - LEVEL OF IMPLEMENTATION}

In many small and medium sized enterprises relatively simple and cheap IT solutions have been used. They are sufficient for activities in local markets and cooperation with local suppliers. As the geographical area of the 
enterprise's activities increases, a system of ERP class which offers significantly greater possibilities in the scope of logistics, is needed. This is a result of the development of network connections [15].

On average, the level of IT system implementation in EU F\&B enterprises was one of the lowest in comparison with other sectors. Average indicator for food processing branch was only 40 (in scale up to 100). It was 9th result within researched 10 branches of economy. The CRM system was used only in 3\% micro-, 4\% small, 17\% medium but $39 \%$ of large firms in the EU-10. EDI systems were used by $3 \%, 10 \%, 17 \%$ and $32 \%$ of firms respectively [18].

One of the most important reasons for introducing IT solutions in the scope of logistics amongst enterprises in the sector was the following: introduction of IT systems by the competition (47\%), requirements of recipients (64\%), expectations of suppliers (41\%), aiming towards competitive advantage (59\%) [18].

\section{BARRIERS}

IT systems for SMEs were not developed in an intensive way due this sector's small demand for IT solutions. The biggest barriers for implementing IT (mainly ERP class software) solutions include the level of complexity (as IT systems) and difficult implementation in SMEs which frequently have insufficient resources in personnel [2, 20, 21].

The relatively small needs and high costs of purchase and implementation of systems of reputable firms mean that many SMEs have their own simple logistics management systems [37]. These are often systems based on simple MS Excel functions. Some standard ERP systems do not always enable the correct modeling of production processes in the food processing branch. This leads to incorrect calculations and reduces the interest in such solutions amongst entrepreneurs [9].

Studies conducted in the EU have confirmed the assumptions of other authors. The biggest barrier if IT implementation in enterprises was the fact that the firm was too small to obtain any benefits from introducing IT systems. Such a reason was given by $56 \%$ of entrepreneurs and $83 \%$ of micro-firms. Other important barriers were high costs of implementation (42\% of responses) and too complicated systems (56\%). These reasons were more frequently given in small firms [18].

Regardless of the barriers associated with the implementation and use of IT systems in SMEs, their role is very important and used in:

- $\quad$ meeting supply deadlines

- efficient production planning,

- $\quad$ high and even use of production capacity

- limiting the amount of work "in progress"

- improving the quality of products and services

- $\quad$ reducing supply costs

- improving the possibility of effective economic process control

- $\quad$ improving communication between organization cells

- better information exchange between recipients and suppliers

- improving competitiveness

- faster circulation of capital

- improvement of cash flow

- cost reduction

- improving profitability (for a wider comparison see Klonowski [24], there is a different perspective from Krygiel [25]).

As Lech [26] claims, the use of modern technology should be associated with organizational changes because technology by itself does not lead to a significant improvement in the productivity of the organization. Lemke pays attention to the need for simulation models in IT systems which in turn can enable their better practical use by way of their wider introduction in the processes of personnel management at various levels [27]. As an effect, such systems will better fulfill their role in the search for sources of competitive advantage. In turn Lis [27] claims that the introduction of IT tools into enterprises is needed to optimize management.

Studies by Rokicki concerning agribusiness enterprises conclude that the branch was the factor which differentiated the scope of IT system use [31]. Therefore research should be carried out into the role of IT systems in logistics enterprises of agribusiness depending on the branch. 


\section{RESEARCH METHODOLOGY}

The aim of the research was to attempt to assess the role of IT systems in supporting logistics processes in agribusiness enterprises. The following research hypothesis was formulated: IT systems support logistics processes in agribusiness enterprises. Additionally it was decided that detailed research hypotheses should be verified: 1) the role of IT systems in supporting logistics systems in agribusiness enterprises is varied in different branches and 2) the role of IT systems in supporting logistics systems in agribusiness enterprises is varied depending on whether it concerns small, medium or large enterprises.

The research was conducted in the form of a questionnaire at the turn of 2009 and 2010. The questionnaires were sent to 8.5 thousand of SMEs qualified to the food processing sector. All entities meeting these criteria were questioned and registered in the REGON database. Moreover, 1.5 thousand micro-enterprises were randomly selected which in total meant that 10 thousand entities were investigated. From such a large sample a return was obtained at a level of $5.1 \%$ and the data obtained were verified from the perspective of data completion. From the large enterprises we obtained $9.7 \%$ returns of questionnaires from medium sized $6.8 \%$, from small $-4.7 \%$, and from micro-enterprises $4.1 \%$. Table 1 presents the number of investigated enterprises divided into branches and sizes.

Table 1. Number of investigated enterprises

\begin{tabular}{|l|r|r|r|r|r|}
\hline \multirow{2}{*}{ Branch } & \multicolumn{7}{c|}{ Size of enterprise } & Large & Total \\
\cline { 2 - 6 } & Micro & Small & Medium & 11 & 117 \\
\hline Meat & 9 & 59 & 38 & 2 & 33 \\
\hline Vegetable & 2 & 18 & 11 & 6 & 24 \\
\hline Diary & 2 & 8 & 8 & 2 & 37 \\
\hline Cereal & 13 & 15 & 7 & 0 & 215 \\
\hline Bakery & 25 & 165 & 11 & 0 & 14 \\
\hline Feed & 2 & 6 & 4 & 7 & 13 \\
\hline Beverages & 5 & 35 & 7 & 29 & 54 \\
\hline Other & 61 & 317 & 100 & & 507 \\
\hline Total & & & & & 0 \\
\hline
\end{tabular}

Source: own research.

The collected data represent data at a nominal or ordinal scale. Therefore the chi-square test could be used. This enabled the investigation of dependencies between selected features and establishing the role of IT systems in supporting logistics systems in agribusiness enterprises, considering the division into branches and on account of enterprise size. The research concerned polish food processing enterprises.

In the studies it was established that the scope of support for the management of logistics processes with the use of IT systems can be examined by separately taking into consideration the level of preparation for automatic reading and storing of information of internal and external processes. It was assumed that the use of specified solutions in firms leads to a higher level of use of IT support.

In order to specify the level of support for internal processes using computer systems, the following things were included: the way stock records were made, the method of identifying product location, product tagging techniques for automatic reading, communication techniques inside the firm. Support for logistics processes implemented partly outside the firm's system was assessed on the basis of using complex IT systems supporting logistics processes, standardization of product tagging and logistics units, communication techniques with external clients.

Each answer was measured in points corresponding with an increasing level of support. For example, records made manually and personal contacts with contractors were given a value of 0, whereas when using ERP class systems and EDI communication, the values given ranged from 1 to 4 . Additionally each such defined feature was given equal significance concerning features within the scope of internal and external process. The maximum grade for each of these groups was 1 . After a points assessment was made, the average level of grades for each area and for all firms was defined. Each firm was classified into either groups of below or above the average level of support. Next the number of companies of different sizes in each of these classes was established. The dependency between the size of the company and the use of IT support for logistics processes was measured using the chi-square test. 


\section{RESULTS}

Figure 1 presents the share of firms that declared usage of comprehensive IT system supporting logistics management.

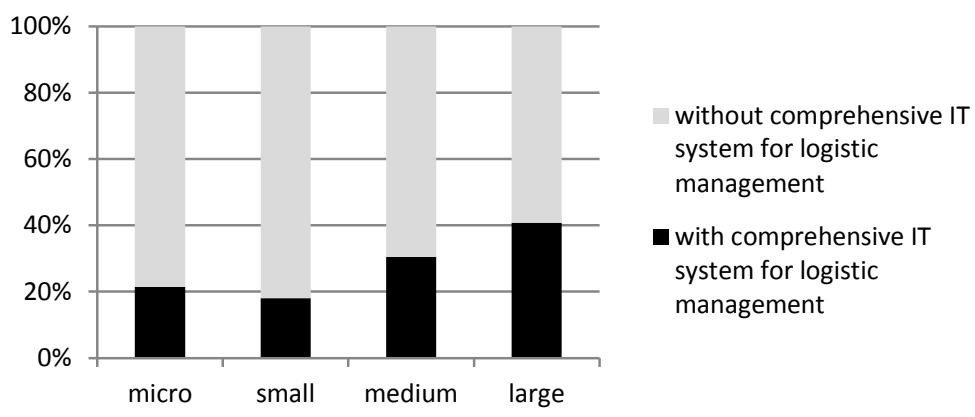

Figure 1. The share of firms with separate IT systems for supporting logistics management Source: Own research.

$\mathrm{N}=465$

The share of firms with IT systems for supporting logistics amounted to an average of $21 \%$. In small enterprises it was 17\%, medium $29 \%$ and large 38\%. A dependency was therefore observed between the size of the enterprise and the IT systems in operation.

The result of the chi2 test shows that the implementation of IT systems supporting logistics management of all areas of the enterprise does depend on the size of the firm. The following result was obtained: $\mathrm{chi}^{2}{ }_{\text {emp. }}=12.15$, $\mathrm{p}$-value $=0.0069$. Figure 2 presents the share of enterprises in which there is a random IT system dedicated to the management of a given area of logistics according to the size of the enterprise.

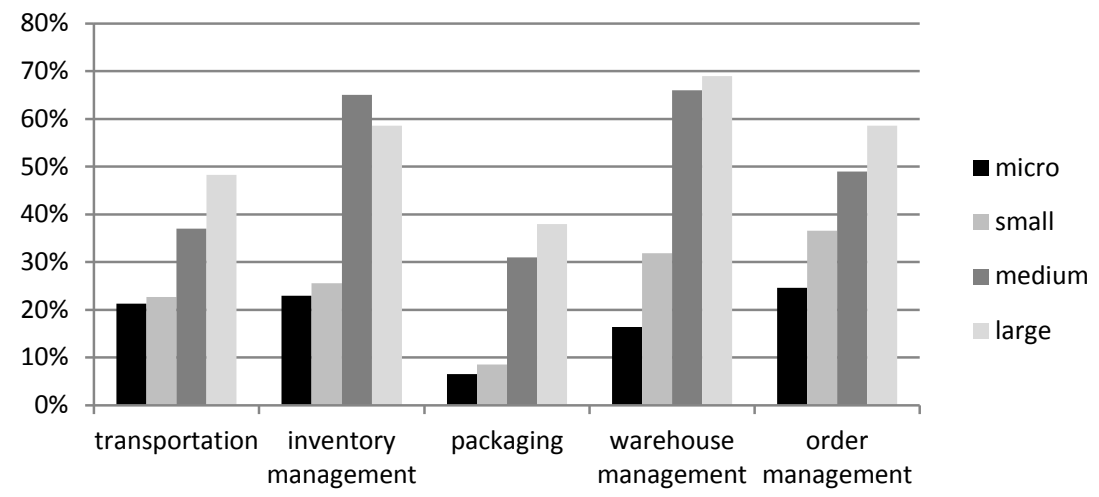

Figure 2. The share of enterprises in which there is an IT system dedicated to the management of a given area of logistics according to the size of the enterprise Source: Own research

It was established that the level of IT tools used for analyzing areas of logistics is much lower in micro and small enterprises. This may be because IT solutions for smaller firms are too costly to purchase and implement and also due to the fact that small enterprises mainly operate in local or regional markets. As research results show, only $15 \%$ of micro-enterprises and $23 \%$ of small enterprises operate in national or international markets. 39\% of medium enterprises however, operate in transnational markets and $62 \%$ of large enterprises. This dependency is confirmed in academic literature. To statistically verify this dependency the chi2 test was used. The results are presented in table 2 .

Table 2. Results of the independence test for existing IT systems supporting particular logistics activity and enterprise size

\begin{tabular}{|l|c|c|c|c|}
\hline Logistics activity & Chi2 & df & chi $_{0.05}$ & p-value \\
\hline Transport & 15.75 & 3 & 7.81 & 0.0013 \\
\hline
\end{tabular}




\begin{tabular}{|l|c|c|c|c|}
\hline Resources & 63.08 & 3 & 7.81 & 0.0000 \\
\hline Packaging & 47.43 & 3 & 7.81 & 0.0000 \\
\hline $\begin{array}{l}\text { Warehouse } \\
\text { management }\end{array}$ & 61.56 & 3 & 7.81 & 0.1096 \\
\hline $\begin{array}{l}\text { Management of } \\
\text { orders }\end{array}$ & 15.01 & 3 & 7.81 & 0.0018 \\
\hline
\end{tabular}

Source: Own research.

The use of IT systems in transport management and the management of orders is similar in all groups of firms. This means that these areas of logistics are informatized first in line. It is worth paying attention to the fact that these are activities directed outside the firm. This may mean that requirements from the side of recipients and suppliers constitute the impulse for introducing IT technology in enterprises as well as the area in which the possibilities for obtaining competitive advantage on the market are searched for. The assessment of IT system class used in the investigated enterprises was made. Simple systems for accounting were widely used. It was observed that higher class IT systems such as (ERP, MRP) were introduced relatively infrequently.

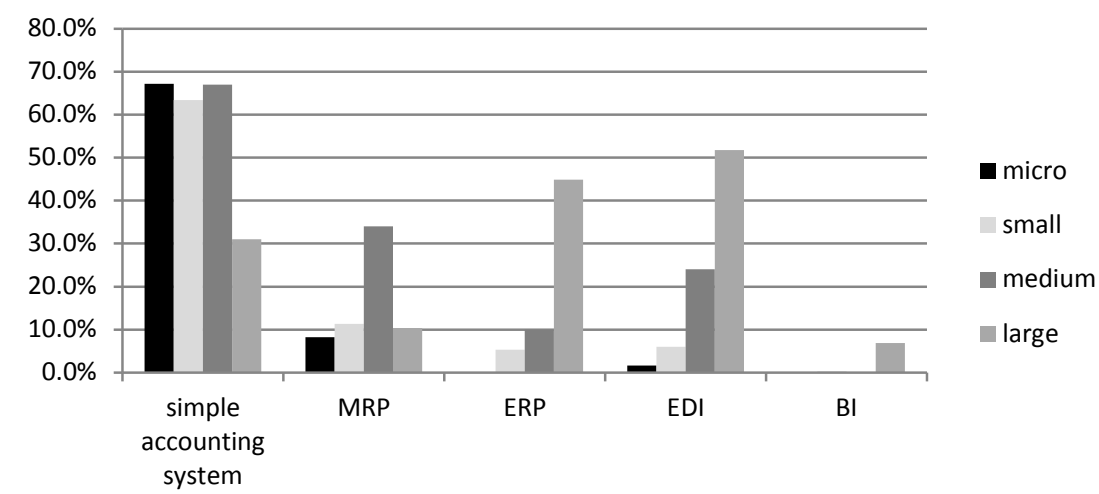

Figure 3. Share of enterprises using particular IT systems for supporting logistics processes (multiple answer allowed) Source: Own research

It is apparent that together with the increase in the size of the enterprise, the share of more advanced IT system technologies also increases. Clear differences were observed between small and medium sized enterprises (fig. 3). Amongst medium sized enterprises a large share possessed MRP class systems, however in medium and large enterprises they were replaced by more advanced ones offering more ERP class systems. In most enterprises (apart from large ones) data deriving from simple accounting systems are used (These dependencies were also considered in subject literature).

As previously, the appearance of dependencies was tested using the Chi-squared test. The results can be observed in table 3. For BI systems a chi2 test was not used because of the small number of classes. The results of the chi2 test indicate a statistically significant dependency between the size of the enterprise and the level of technological advancement of IT system classes.

Table 3. Results of the independence test for existing IT system supporting particular logistics activity and enterprise size

\begin{tabular}{|l|c|c|c|c|}
\hline $\begin{array}{c}\text { IT system used in } \\
\text { logistic management }\end{array}$ & Chi2 & df & chi $_{0.05}$ & p-value \\
\hline $\begin{array}{l}\text { Simple accounting } \\
\text { system }\end{array}$ & 13.83 & 3 & 7.81 & 0.0032 \\
\hline MRP & 33.56 & 3 & 7.81 & 0.0000 \\
\hline ERP* & 55.37 & 2 & 5.99 & 0.0000 \\
\hline EDI & 74.99 & 2 & 5.99 & 0.0000 \\
\hline
\end{tabular}

* two classes micro and small enterprises were consolidated because of a lack or too small number of enterprises with ERP and EDI within the micro-enterprises group

Source: Own research. 
Figure and table 4 present the communication techniques with suppliers and recipients depending on the size of the enterprise and the frequency of using defined channels of communication. Variability was observed in the scope of dependencies on the size of the enterprise and method of communication. The most frequent method of communication in all groups of enterprises was the telephone, whereas "paper communication" was less frequent. A marked variation was observed with regard IT communication, which was used most frequently in large enterprises.

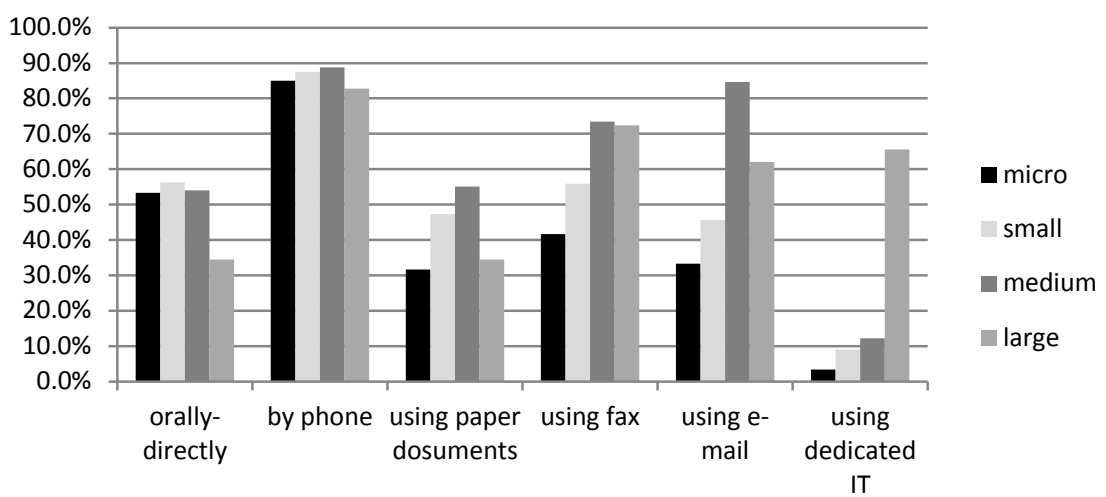

Figure 4. Techniques of communications to suppliers and customers in researched companies depend on company size (multiple answer) Source: Own research.

Table 4. Results of the independence test for communication channel use and enterprise size

\begin{tabular}{|l|r|r|r|c|}
\hline \multicolumn{1}{|c|}{$\begin{array}{c}\text { Communication } \\
\text { channel }\end{array}$} & Chi2 & df & chi 0.05 & p-value \\
\hline Verbal - directly & 4.61 & 3 & 7.81 & 0.2029 \\
\hline By phone & 0.56 & 3 & 7.81 & 0.9064 \\
\hline By fax & 18.95 & 3 & 7.81 & 0.0003 \\
\hline Using e-mail & 55.28 & 3 & 7.81 & 0.0000 \\
\hline Using paper media & 9.50 & 3 & 7.81 & 0.0233 \\
\hline Using EDI & 85.86 & 3 & 7.81 & 0.0000 \\
\hline
\end{tabular}

Source: Own research.

Various methods of communication were used with contractors in the investigated enterprises. In each enterprise a few basic methods of communication were used simultaneously. Regardless of the size of the company the direct channel (person to person) contact method with contractors was used (for example during delivery). Telephone communication was also commonly used. This included making, changing and confirming orders. Paper documents were widely used. Only large firms widely used electronic EDI system documentation. What is interesting is the fact that the use of paper documents both in micro-enterprises and large firms was least common. In micro-enterprises face to face contact was more common, without the use of formal documentation. In large firms electronic documents replaced paper ones. A statistically significant variation was observed in the use of faxes and e-mails. These observations were confirmed by the chi2 test (table 4). For the remaining variables no difference was observed between enterprises of various sizes.

In the final stage of analysis an assessment was made as to whether the use of IT systems in logistics is the same in all investigated branches of agribusiness. The following branches were distinguished for analysis: meat processing, milk, vegetables and fruits, beverages, cereals, the bakery industry, and others. Those branches whose number was less than 10, were not included. Therefore tobacco producers, oil processing and feed production were not included. The results were presented in graph 5 and the results of the chi2 test were shown in table 5 . 


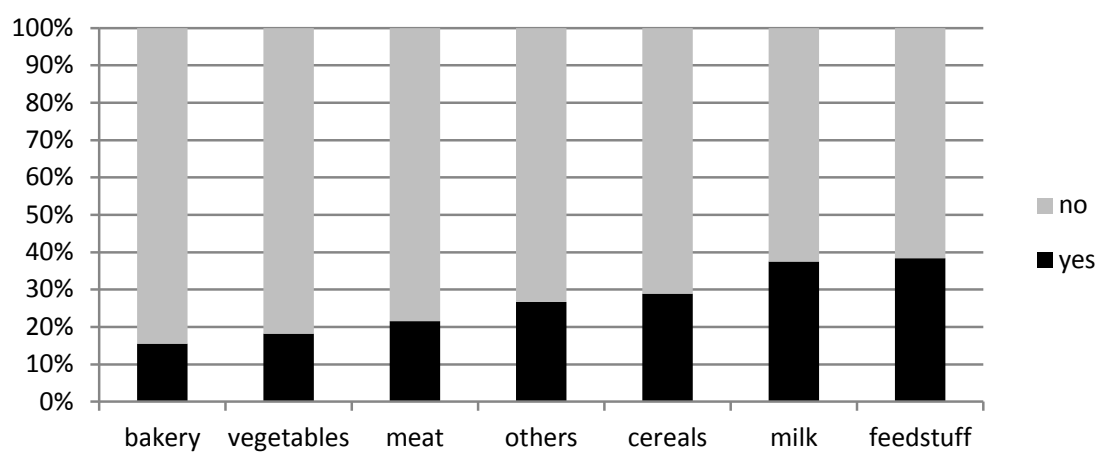

Figure 5. Differences in using one integrated IT solution for the entire logistics activity management in food processing branches Source: Own research.

The use of integrated IT systems in logistics management varies depending on the branch. The share of firms with such systems was highest amongst cereal, milk and fodder processing. The bakery, vegetable and fruit processing and meat processing branches used such solutions least frequently. Initial analysis shows that the result is associated with the average scale of production in a given branch and the size of the market served.

The results of the independence test for using one IT system supporting the entire logistics enterprise and food industry branch. It was observed that the frequency of IT systems appearing in the complex support of the whole logistics enterprise does not depend on the branch. The following result was obtained chi ${ }_{\text {emp. }}=12.74$, $\mathrm{p}$ value $=0.0474\left(\mathrm{df}=6, \mathrm{chi}_{0.05}=12.59\right)$. There is no statistical dependency, whilst the frequency of using IT systems varies and depends on the food industry branch.

It was established (table 5) that the average grade of support for internal logistics systems was equal to 0.27 for internal and 0.33 for external processes. Such a difference was observed in each group of firms. This means that contact with clients who use electronic tools of communication has led to a greater scope of IT system implementation. One can ascertain that the requirements of external clients and activities over a wide geographical area have led to the implementation of IT support for (internal and external) processes. The lowest level of support was observed in micro-firms and as expected support grew with the increase in the size of the firm. The observed level of 0.6-0.7 in large companies means that not all of them implemented the assessed solutions in full, for example did not use RFID and/or EDI.

Table 5. Results of evaluation of level of IT support for logistics processes

\begin{tabular}{|l|c|c|c|c|c|}
\hline \multirow{2}{*}{\multicolumn{1}{c|}{ Processes }} & \multicolumn{5}{c|}{ Company size } \\
\cline { 2 - 6 } & Micro & Small & Medium & Large & All companies \\
\hline Internal processes & 0.18 & 0.22 & 0.39 & 0.57 & 0.27 \\
\hline External processes & 0.25 & 0.28 & 0.45 & 0.66 & 0.33 \\
\hline
\end{tabular}

Source: Own research.

An aggregated result is obtained. The areas that obtained the highest grades within the scope of internal processes are: MRP or ERP class IT systems in the management of stock and standardization of logistics unit tagging and their location in warehouses. In external processes, the highest grade was obtained in the service of orders, including the use of standard EDI messages.

Diagram 6 presents the participation of enterprises which achieved a higher than average grade for the support of logistics processes using IT solutions according to the size of the firm. Only $25 \%$ of micro-firms achieved an average level. The vast majority of companies in which the level of support for both internal and external processes was observed amongst medium and large enterprises. This results from a greater complexity of processes in these companies, a larger number of clients and activities over a greater geographical area - local, the whole country and often abroad. A tight correlation can be observed between the distinguished groups of processes (The Pearson correlation coefficient is equal to 0.89). This means that the introduction of IT support for logistics processes is usually complex, whilst the available systems enable the improvement of both internal and external logistics processes. 


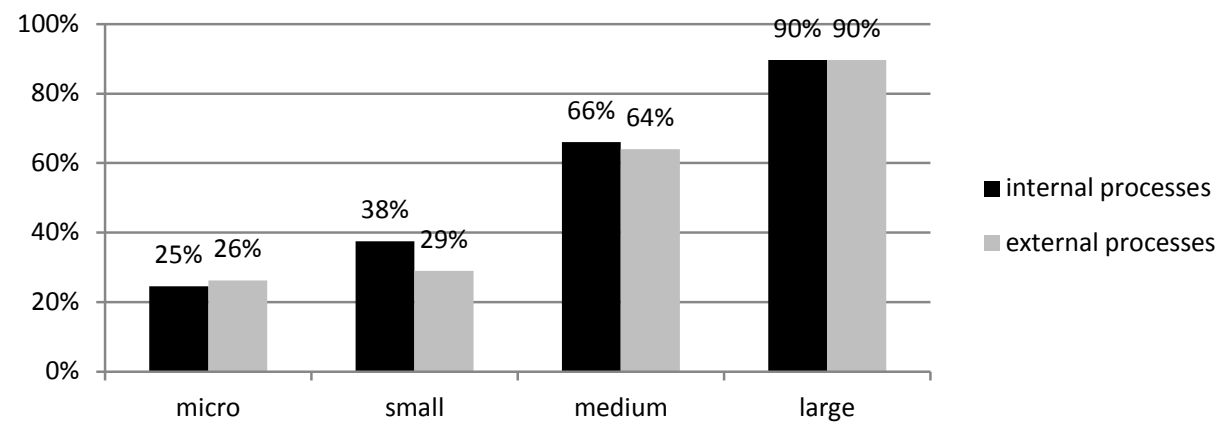

$\mathrm{N}=507$

Fig. 6. The share of firms with level of advancement of logistic processes support which is above average for the researched group Source: Own research.

Despite clear differences between the firms of different sizes, a chi-square test was made with the purpose of defining whether there is a dependency between the size of the firm and the level of IT support for logistics processes. The results are presented in table 6. It was stated that the level of support for both internal and external processes using IT systems is strongly dependent on the size of the firm. In those enterprises employing 50 persons or less the level of advancement was relatively low but increased in medium and large firms.

Table 6. Results of the independence test for existing IT systems supporting internal and external logistic

\begin{tabular}{|l|r|r|r|r|}
\hline \multicolumn{1}{|c|}{ Group of processes } & \multicolumn{1}{|c|}{ Chi2 } & df & \multicolumn{1}{c|}{ chi $_{0.05}$} & \multicolumn{1}{c|}{ p-value } \\
\hline Internal processes & 58.65 & 3 & 7.81 & 0.0000 \\
\hline External processes & 74.96 & 3 & 7.81 & 0.0000 \\
\hline
\end{tabular}

Source: Own research.

\section{CONCLUSIONS}

The implementation of IT systems in logistics enterprises is a requirement resulting from the progress of information technology and economic globalization. This is a method of not only improving logistics processes in enterprises but also a source of obtaining competitive advantage on the market, which leads to an improved financial situation of the enterprise. Analysis shows that there is significant internal variation within the scope of the food production sector with reference to the scope of IT system use in logistics management. These results stem from the various features of the materials, level of concentration in the branch and the character of recipients. In the service of wholesalers or retail chains the implementation of IT systems is required at least within the scope of the management of orders. Further conclusions may result from deeper analysis in this area. However, without doubt the food sector is a field in which the implementation, range and pace of IT system implementation will be increasing. For more detailed indications concerning the size of IT system solutions required to support logistics operations and other processes of the firm - a continuation of studies is necessary.

\section{FINDINGS OF RESEARCH}

Due to the influence of IT systems in obtaining a competitive advantage of enterprises, their implementation is recommended. However, attention should be paid to the appropriate adjustment of systems to the needs of the enterprise, depending on its size (less complicated and cheaper systems can support the development of micro and small enterprises without them incurring high costs). Additionally it is worth paying attention to the holistic approach to the implementation and use of IT systems in logistics to enable the smooth running of the enterprise and combine effective work with the effective use of functional possibilities of IT systems.

\section{LIMITATIONS}

The studies conducted cannot be generalized and fully applied to all logistics enterprises in the food branch. The limitations above all concern micro-enterprises that were the lowest number represented in the selected sample. Additionally, due to the statistically significant dependencies presented between the size of the enterprises and chosen features characterizing their use of IT systems, further studies seem to be necessary. These will enable the specification of further important features characteristic for particular groups of enterprises and will give the 
possibility of detailed recommendations depending on whether they concern micro, small, medium or large logistics enterprises of the food branch.

\section{REFERENCES}

1. Abt S. (2000). Wdrażanie systemów logistycznych w Polsce, [w]: Logistics 2000, Wyjść naprzeciw logistycznym wyzwaniom XXI wieku. Polski Kongres Logistyczny, Poznań 1-2 czerwca 2000. Materiały kongresowe [red.] J. Wojtczak, ILiM, Poznań, pp. 281-297.

2. (2006). Accelerating e-collaboration with Internet EDI. Manufacturing and Logistics IT, February 2006, pp. 74-75.

3. Angeles, R. (2005). RFiD technologies: Supply chain application and implementation issues. Information System Management, no 22, 51-64. doi: 10.1201/1078/44912.22.1.20051201/85739.7.

4. Avila O., Goepp V., Kiefer F. (2009). Understanding and classifying information system alignment approaches, Journal of Computer Information Systems, 50/1, pp. 2-14.

5. Basten D., Joosten D., Mellis W. (2011). Managers' Perceptions of Information System Project Success, Journal of Computer Information Systems, 52/2, pp. 12-21.

6. Borowiec B. (2006). Zarządzanie wiedzą z punktu widzenia twórców systemów informatycznych, Studia i Materiały - Wydział Zarządzania UW, 1/2006, pp. 63-67.

7. Chwesiuk K. (2011). Analiza porównawcza systemów informatycznych wspomagających zarządzanie w logistyce dystrybucji, Logistyka 3/2011, pp. 407-417.

8. Csaba, I., Komaromi, N., Lehota, Z, (2008). Traceability in Hungarian Fresh Vegetable and Fruit Sector: A transacton Costs Economic Approach. Roczniki Naukowe SERiA, z. 5, vol. X. pp. 26-31.

9. (2010). Essential Guide to ERP for Food Processing Companies. available on: http://www.foodprocessing.com/whitepapers, pp. 1-24.

10. Fadel K.J. (2011). User adaptation and infusion of information system, Journal of Computer Information Systems, 52/3, pp. 1-10.

11. Fishkin, K. P. Roy, S., Jiang, B. (2005). Some methods for privacy in RFiD communication. Security in adhoc and Sensor Networks, Springer, Berlin-Heidelberg, pp. 42-53.

12. Folinas D., Vlachopoulou M., Manthou V., Manos B. (2003). A web based integration of data and processes in the agribusiness supply chain. EFITA 2003 Conference, Debrecen, Hungary, pp. 143-149.

13. Garcia Perez, A, Garcia Martinez, M., (2007). The agrifood cooperative netchain. A theoretical framework to study its configuration. Food Economics - Acta Agricult. Scand. C, 4, pp. 31-39.

14. Grębowiec M. (2012). Systemy informacyjne i ich zastosowanie w logistyce produktów żywnościowych, Logistyka 4/2012, pp. 947-959.

15. Harrison B., (2010). Create the forecasting and planning experience you want with DSX. Manufacturing and Logistics IT, March 2010, pp. 22-23.

16. Hobbs, J. (2004). Information asymmetry and the role of traceability systems. Agribusiness, Vol. 20, Issue 4, pp. 397-415.

17. Hołubowicz W., Samp K. (2008). Informacja i informatyka w logistyce, [w] Nowe wyzwania nowe rozwiązania materiaty konferencyjne, Janiak T. Konferencja polskiego kongresu logistycznego Logistics 2008, pp. 57-66.

18. (2006). ICT and e-Business in the Food and Beverages Industry. ICT adoption and e-business activity in 2006. European Commision. pp., 172.

19. Grabowska J. (2012), Model systemu informacji logistycznej w kanałach dystrybucji węgla kamiennego, Praca doktorska, Politechnika Śląska, Wydział Organizacji i Zarządzania, pp. 1-27.

20. Jałowiecki P., Orłowski A., (2010). Technologie informatyczne w logistyce. Wieś Jutra nr 1 (138), styczeń 2010, pp. 36-37.

21. Jałowiecki, P., Wicki, L., (2010). Zróżnicowanie poziomu organizacji logistyki w wybranych branżach agrobiznesu. Logistyka nr 3, pp. 1-21.

22. Kaleta M., Toczyłowski E. (2009). Rola informatyki w zwiększaniu efektywności rynku energii, Rynek Energii 1(80)/2009, pp. 66-73.

23. Kanicki T. (2011). Systemy informatyczne w logistyce, Economy and Management - 4/2011, pp. 87-97.

24. Klonowski Z.J. (2004). Systemy informatyczne zarządzania przedsiębiorstwem modele rozwoju i właściwości funkcjonalne, Oficyna Wydawnicza Politechniki Wrocławskiej, Wrocław.

25. Krygiel J. (2011). Rola logistyki dystrybucji w kształtowaniu pozycji konkurencyjnej firm na polskim rynku IT, [w] Zarządzanie logistyczne [red.] K. Kolasińska-Morawska, Przedsiębiorczość i Zarządzanie T. XII, Z. 9, Copyright by Społeczna Wyższa Szkoła Przedsiębiorczości i Zarządzania, Łódź, pp. 97-108.

26. Lech P. (2003). Zintegrowane systemy zarządzania ERP/ERP II, charakterystyka, wykorzystanie w biznesie, wdrażanie, Difin, Warszawa. 
27. Lemke J. (2009). Rola symulacji w zintegrowanych systemach informatycznych zarządzania, Zeszyty Naukowe Akademia Morska w Szczecinie, 16/88, pp. 59-62.

28. Lis T. (2011). Informatyczne wspomaganie zarządzania logistycznego w obszarze transportu $\mathrm{w}$ przedsiębiorstwach handlowych - założenia do systemu, Logistyka 6/2011, pp. 2239-2249.

29. Palonka J. (2008). Narzędzia technologii informacyjnej wykorzystywane w logistyce w e-gospodarce, [w] Systemy Wspomagania Organizacji [red.] M. Pankowska, T. Porębska-Miąc, H. Sroka, Wydawnictwo AE w Katowicach, Katowice.

30. Rai A., Patnayakuni R., Patnayakuni N. (2006). Firm Performance Impacts of Digitally Enabled Supply Chain Integration Capabilities, Management Information Systems Quarterly, Vol. 3, Iss. 2, pp. 225-246.

31. Rokicki T., (2012). Wsparcie informatyczne procesów logistycznych w przedsiębiorstwach agrobiznesu, Logistyka 6/2012, pp. 561-568.

32. Ruiz-Garcia, L., Lunadei, L., Barreiro, P., Robla, I., (2009). a REVIEW OF Wireless Sensor Technologies and Applications in Agriculture and Food Industry: State of Art. and Current Trends. Sensors, no 9, pp. 4728-4750. doi: 10.3390/s90604728.

33. Smal Sz., (2011). Zdalna kontrola nad zachodzącymi w magazynie procesami to przyszłość rozwiązań IT dla logistyki [in] Raport Manufacturing Systems Information Polska 2011/2012, grudzień (2011). www.msipolska.pl, dostęp 30.04.2013 r., (p. 18), pp. 1-32.

34. Vorst, J. van der, (2000). Effective food supply chains, generating modeling and evaluating supply chain scenarios. University of Wageningen, pp. 305.

35. Vorst, J van der, (2004). Performance levels in food traceability and the impact on chain design: results on an international benchmark study. [in:] Dynamics in chain and networks. (eds. Bremmers, H., Omta, S., Trienkens, J., Wubben E.) Wageningen Academic Publishers. Wageningen, The Netherlands. pp. 175-183.

36. Vorst, J van der, (2006). Product traceability in supply chains. Accred. Qual. Assur., no 11, pp. 33-37, doi: 10.1007/s00769-005-0028-1.

37. (2008), Top 20 supply chain management software suppliers. Modern Material Handling, July 12008.

38. Wyrębek H. (2011). Zintegrowany system informatyczny w zarządzaniu logistyką, Zeszyty Naukowe Uniwersytetu Przyrodniczo-Humanistycznego w Siedlcach Nr 90, Seria: Administracja i Zarządzanie (17)2011, pp. 209-221.

39. Zhou, J., Shi, J. (2009). RFiD localization algorithms and applications - a review. J. Intell. Manuf. (2009), no 20, 695-707. doi: 10.1007/s10845-008-0158-5. 